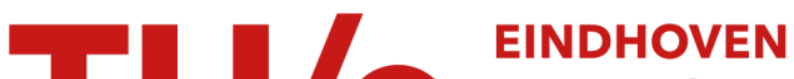 \\ UNIVERSITY OF \\ TECHNOLOGY
}

\section{Design of sensors for in-flight lightning detection on aircrafts}

\section{Citation for published version (APA):}

Deursen, van, A. P. J., \& Stelmashuk, V. (2009). Design of sensors for in-flight lightning detection on aircrafts. In Proceedings of 11th international conference on Electromagnetics in Advanced Applications (ICEAA '09), 14-18 September 2009, Turin, Italy (pp. 825-828). Institute of Electrical and Electronics Engineers.

https://doi.org/10.1109/ICEAA.2009.5297341

DOI:

10.1109/ICEAA.2009.5297341

Document status and date:

Published: 01/01/2009

\section{Document Version:}

Publisher's PDF, also known as Version of Record (includes final page, issue and volume numbers)

\section{Please check the document version of this publication:}

- A submitted manuscript is the version of the article upon submission and before peer-review. There can be important differences between the submitted version and the official published version of record. People interested in the research are advised to contact the author for the final version of the publication, or visit the $\mathrm{DOI}$ to the publisher's website.

- The final author version and the galley proof are versions of the publication after peer review.

- The final published version features the final layout of the paper including the volume, issue and page numbers.

Link to publication

\section{General rights}

Copyright and moral rights for the publications made accessible in the public portal are retained by the authors and/or other copyright owners and it is a condition of accessing publications that users recognise and abide by the legal requirements associated with these rights.

- Users may download and print one copy of any publication from the public portal for the purpose of private study or research.

- You may not further distribute the material or use it for any profit-making activity or commercial gain

- You may freely distribute the URL identifying the publication in the public portal.

If the publication is distributed under the terms of Article 25fa of the Dutch Copyright Act, indicated by the "Taverne" license above, please follow below link for the End User Agreement:

www.tue.nl/taverne

Take down policy

If you believe that this document breaches copyright please contact us at:

openaccess@tue.nl

providing details and we will investigate your claim. 


\title{
Design of sensors for in-flight lightning detection on aircrafts
}

\author{
A.P.J. van Deursen ${ }^{1} \quad$ V. Stelmashuk ${ }^{2}$
}

\begin{abstract}
In the EU FP6 project ILDAS a prototype In-flight Lightning Damage Assessment System is developed for passenger aircraft and helicopter. The project aims to localize the attachment and the severity of the strokes during flight to assist maintenance. A database of events will be constructed to substantiate requirements for aircraft lightning immunity. Inductive magnetic field sensors are put at various positions on the aircraft. The sensors are followed by passive/active integrators to deal with the large dynamic range and bandwidth, and by high speed data conversion/storage. The paper focuses on design and tests of three types of sensors.
\end{abstract}

\section{INTRODUCTION}

Passenger aircraft are on average struck by lightning once a year. The 'In-flight Lightning Strike Damage Assessment System' (ILDAS) EU [1] project aims to develop and validate a prototype of a system capable of in-flight measurement of the points of attachment and characteristics of actual lightning strikes. Magnetic field sensors are an obvious choice to determine the local current density through the aircraft structure during strokes.

In the lightning current two types of components can be distinguished, a slow quasi-continuous current of up to several hundreds ampere with a duration of the order of 1 second, and fast components, initiating $\mu \mathrm{s}$-fast current pulses up $1 \mathrm{kA}$ and the large strokes up to $200 \mathrm{kA}$. A split system has been chosen to deal with both types, one coil adapted for low frequencies (LF, between $1 \mathrm{~Hz}$ and about $300 \mathrm{~Hz}$ ) and another for the higher frequencies (HF, between $100 \mathrm{~Hz}$ and 10 $\mathrm{MHz}$ ). The system should also localize the lightning attachment, or at least indicate regions that can be excluded in a maintenance search. To this end a limited number of sensors survey points chosen in a study that included many lightning scenarios. Among these points are the wings and the fuselage. On the wings, the flap track fairings often have sufficient space to place the coils and electronics for signal conditioning. Here we chose small pick-up coils, per position and per field orientation one for HF and one for LF. For the fuselage we invented a novel sensor that can be fitted in a window and does not protrude outside the aircraft. It relies on the partial penetration of lightning magnetic field through a window opening in the metal fuselage. The sensor poses only small obstruction of view through the window.

\section{COIL SENSORS}

The scenario study also resulted in a dynamic range required for the various positions. In the flap track fairings the magnetic field components were below $30 \mathrm{kA} / \mathrm{m}$ for the HF. A three turn coil is made of rigid coax. Its a total flux capturing area of $100 \mathrm{~cm}^{2}$ suffices for the strokes. Resistances mounted halfway along the windings damp undesired resonances. The total space required per coil is a cube of $8 \mathrm{~cm}$ on a side.

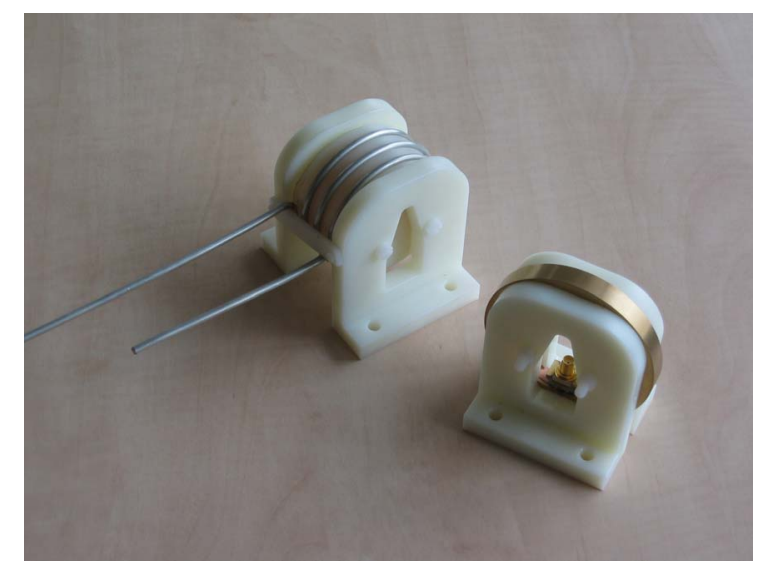

Figure 1. HF coil (left) and shielded LF coil (right) without connectors mounted.

The LF coil is primarily intended for the quasicontinuous current. It should have a dynamic range starting at a few $\mathrm{A} / \mathrm{m}$, and be able to cope with the stroke's field. A many turn coil with large flux capturing area $\left(0.64 \mathrm{~m}^{2}\right)$ can then be mounted inside a metal toroidal shield designed to pass frequencies below several hundreds $\mathrm{Hz}$, and filter all $\mathrm{HF}$ to such an extent that the LF channel does not clip at the strokes. The $\mathrm{L} / \mathrm{R}$ time constant of the brass torus actually made is approximately $300 \mathrm{~Hz}$, the thickness of the wall provides additional shielding by the skin effect above $2 \mathrm{kHz}$. The coil space requirement is again a cube of $8 \mathrm{~cm}$ on each edge.

${ }^{1}$ Department of Electrical Engineering, Eindhoven University of Technology, The Netherlands

e-mail: a.p.j.v.deursen@tue.nl, tel.: +31 402474434 , fax: +31402450735.

${ }^{2}$ Department of Electrical Engineering, Eindhoven University of Technology, The Netherlands, Now at Institute of Plasma Physics, Za Slovankou 3, 18200 Prague 8, Czech Republic. e-mail: vitalij@ipp.cas.cz, tel.: +420 266053238. 


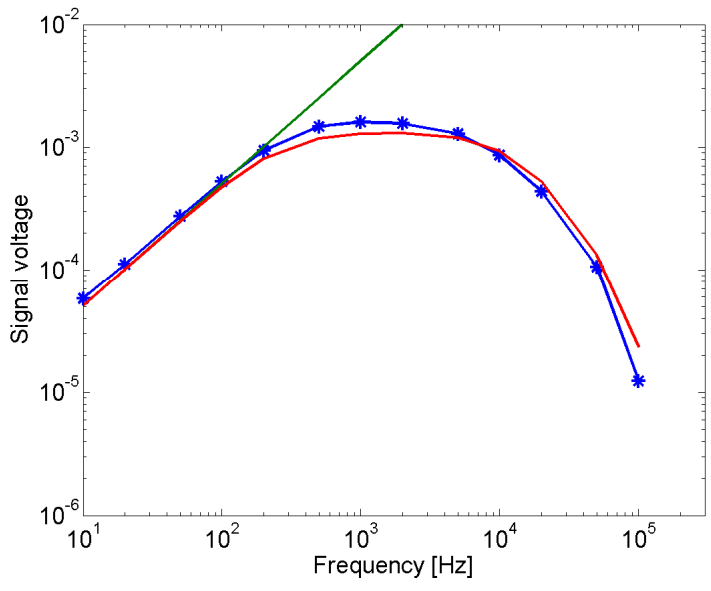

Figure 2. Signal from LF coil for $H_{0}=1 \mathrm{~A} / \mathrm{m}$ as function of frequency. The L/R cut-off occurs at 300 $\mathrm{Hz}$; from $2 \mathrm{kHz}$ the skin effect provides additional shielding.

The LF coil transfer has been tested in a Helmholtz' setup. The response as a function of frequency is displayed in Fig. 2. The transfer can be described by the inductive pick-up (green line) times a shielding factor $Q$ given by $Q=Z_{t} /\left(Z_{s}+j \omega L_{r}\right)$ with $Z_{t}$ the transfer impedance of the torus considered as a ring, $Z_{s}$ the surface impedance of the ring, and $L_{r}$ the inductance of the ring. Analytical approximations for $Z_{t}, Z_{s}$ and $L_{r}[2]$ are

$$
\begin{gathered}
Z_{t}=R_{0} \frac{k d}{\sinh k d}, \\
Z_{s}=R_{0} \cdot k d \operatorname{coth} k d,
\end{gathered}
$$

and

$$
L_{r} \simeq \mu_{0} r_{a}\left(\log \frac{8 r_{a}}{r_{i}}-2\right),
$$

with $R_{0}$ the d.c. resistance of the ring, $k=(1+j) / \delta$ and $d$ the wall thickness $(3 \mathrm{~mm})$ of the ring. The penetration depth equals $\delta=\sqrt{2 \rho / \mu_{0} \omega}$ with common definitions for the parameters. The ring major radius is $r_{a}(35 \mathrm{~mm}), r_{i}$ is the equivalent minor radius $(5$ $\mathrm{mm})$. The prototype torus used brass $(\rho=7 \mu \Omega \mathrm{cm})$ as material for easy manufacturing. The red curve in Fig. 2 displays the calculated response without any adjustment of parameters.

\subsection{Coil tests in high field}

Among the tests applied, both coils were subjected to the magnetic field of $16.7 \mathrm{kA} / \mathrm{m}$ amplitude generated by a near-to-critically damped $15 \mathrm{kHz} \mathrm{L} / \mathrm{C}$ circuit. Each coil was followed by a special combined active/passive integrator; the frequencies for $0 \mathrm{~dB}$ gain were $800 \mathrm{~Hz}(\mathrm{HF})$ and $400 \mathrm{~Hz}$ (LF). The active part ensured an integrating characteristic down to 100 $\mathrm{Hz}$ (HF) or $1 \mathrm{~Hz}$ (LF). The main goal of the test was the show that the LF signal channel remains within its dynamic range of $1 \mathrm{kA} / \mathrm{m}$ in the presence of the stroke-like field. The output of both channels is given in Fig. 3.

With the short $16.7 \mathrm{kA} / \mathrm{m}$ pulse, the output of the LF channel remained below $500 \mathrm{~A} / \mathrm{m}$. The dynamic range of the $\mathrm{LF}$ channel is $1 \mathrm{kA} / \mathrm{m}$. Even a full fast stroke of $30 \mathrm{kA} / \mathrm{m}$ will not cause an overload of the LF channel. The LF channel droop after $100 \mu \mathrm{s}$ is mainly caused by the dominant L/R time of the torus shield. The frequency dependence of both channels is well known. As a result, the signal of both channels can be combined later to restore the full actual waveform of the short strokes plus the quasicontinuous current.

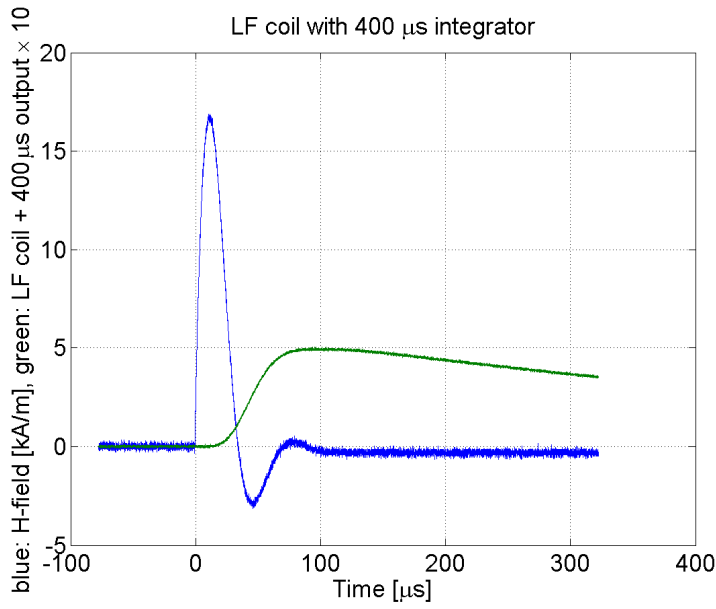

Figure 3. Reponse of HF (blue) and LF coil (green, $\times 10)$ on a pulse of $16.7 \mathrm{kA} / \mathrm{m}$ and $30 \mu$ s duration.

\section{WINDOW SENSOR}

A current $I$ through the fuselage generates a magnetic field $H_{0}=I / 2 \pi r_{f}$ outside the fuselage (with radius $\left.r_{f}\right)$. There is no field due to $I$ inside the fuselage considered as a solid tube. For our analysis, the fuselage can be approximated as a flat plane near the window, where the current flows around the hole and causes the field to enter and leave the window, as shown in Fig. 4. A coil is wound in a figure ' 8 ' with a bar over the middle line of the window and with the outer perimeter of the ' 8 ' closely against the fuselage at some distance of the window. The bar of the ' 8 ', can be two thin twisted wires inserted in the insulating space between the window panes. The coil captures the flux $\Phi_{0}$ that enters the top half and also the flux that leaves the bottom halve of the window. 

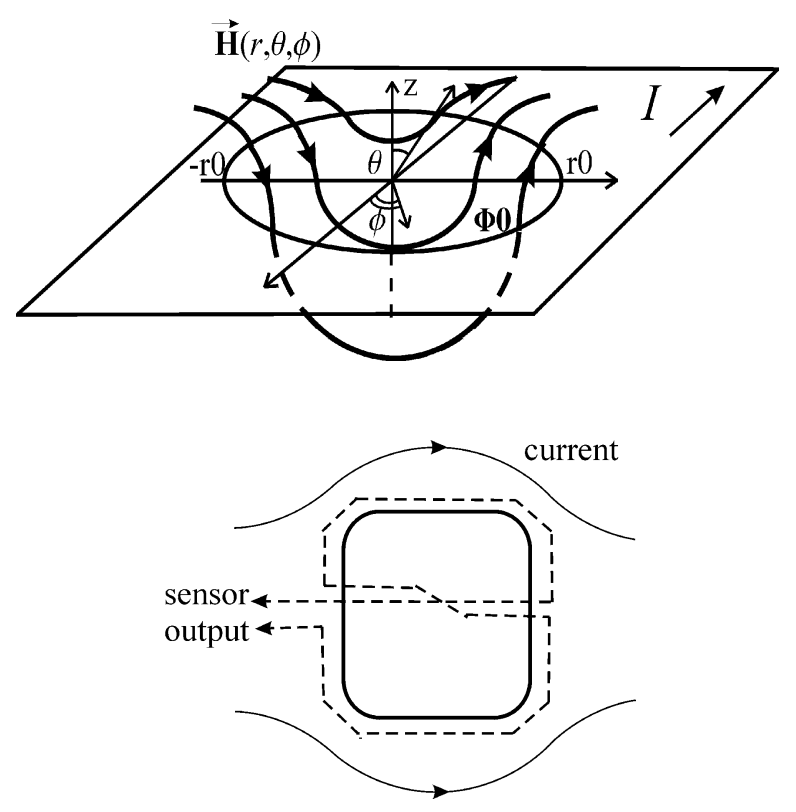

Figure 4 Top: Schematic presentation of the magnetic field penetration through a hole in a flat plate.

Bottom: Sensor windings over a window and current distribution near the window.

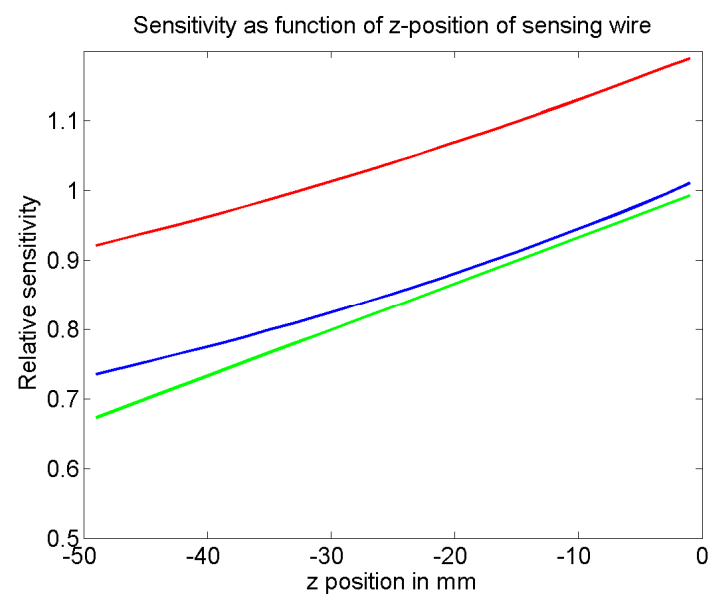

Figure 5. Sensitivity of the window sensor, extending $400 \mathrm{~mm}$ over the window, as a function of the distance $d=-z$ over the circular hole. Green: analytical approximation mentioned above, blue: MoM result, red: result for an actual window shape. All sensitivity values are normalized to $H_{0} r_{0}{ }^{2}$ with $r_{0}$ the radius of $150 \mathrm{~mm}$ for the circular hole.

A second way to describe the action of the coil: the outer perimeter is in a field-free region, whereas the bar senses the induced electric field over the window middle line. It does so twice for the figure ' 8 '. The principle has been shown to work well in lightning tests on a Nimrod airplane [3].

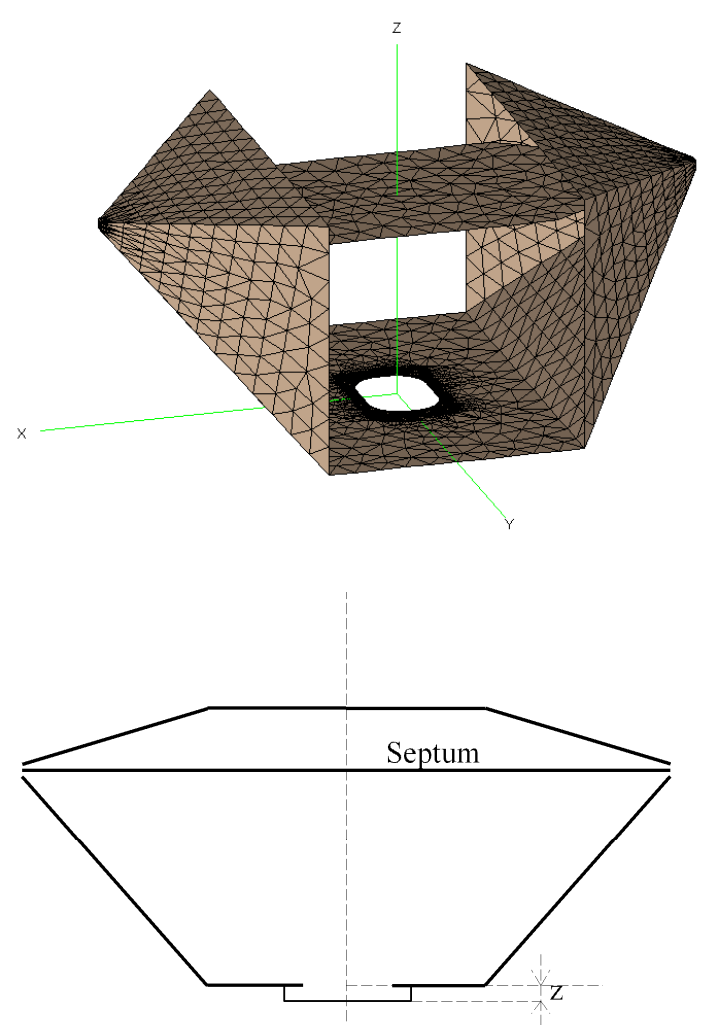

Figure 6 Top: Feko MoM model of the TEM cell, with side walls and top removed to show the septum and the window hole in the bottom.

Bottom: Mid-cell cross section and position $\mathrm{z}=-d$ of the $400 \mathrm{~mm}$ long sensor wire under the hole.

\subsection{Sensitivity calculation for the window sensor.}

The field coupling through a circular hole in a thin plane is an old problem. Analytical expressions are given in [4, Sect. 5.13] for the field inside the hole in a thin flat plane. The in-plane field is $H_{0} / 2$, the perpendicular field component in the hole is $H_{z}(r, \varphi)=\left(2 H_{0} r \sin \varphi\right) / \pi \sqrt{r_{0}^{2}-r^{2}}$ (see Fig. 4). When $H_{z}$ is integrated over the half circle $0<\varphi<\pi$, the flux becomes $\Phi_{0}=H_{0} r_{0}^{2}$. The figure ' 8 ' captures this flux twice. It should be noted that this sensitivity is expressed in the field $H_{0}$ that would be at the position of window without the window. It is unlikely that the bar can be put exactly in the plane of the fuselage; it will rather follow a path at some distance $d$ inside the fuselage and extend over some distance from the window edge. The missed flux can be derived from the in-plane field $\Delta \Phi=d r_{0} H_{0}$, to be counted twice again for the figure ' 8 ' coil.

In order to assess the sensitivity for an actual window, we modeled the hole in the bottom of a large TEM cell by a MoM calculation [5]. An 
available cell was taken as model; its width is $1.4 \mathrm{~m}$ and length $0.9 \mathrm{~m}$. This size avoids excessive influence from the edges. First we calculated the electric field over a circular opening of radius $r_{0}=$ $0.15 \mathrm{~m}$. Agreement with the analytical expression $H_{0} r_{0}^{2}$ and $d r_{0} H_{0}$ was observed to within 2 percent for positions of the sensor wire up to $1.5 \mathrm{~cm}$ from the wall. For larger $d$ the variation becomes smaller (see Fig. 5). Secondly, a window sized hole was modeled in the TEM cell bottom: a rounded rectangle of 0.25 $\mathrm{m} \times 0.35 \mathrm{~m}$; see Fig. 6. Again the sensitivity was calculated for a sensor wire of $0.4 \mathrm{~m}$ length, at a distance $z$ from the bottom. The result is also shown in Fig. 5, expressed as sensitivity in units of $\mathrm{H}_{0} \mathrm{r}_{0}{ }^{2}$ belonging to the circular opening sensed once. Extrapolated to the position $z=0$ against the bottom, the sensitivity of this sensor is 1.20 compared to the circular window with a radius of $r_{0}=0.15 \mathrm{~m}$. The long window axis forces the current more outwards, and thereby increases the flux.

\subsection{Experimental verification on a small scale model}

We adapted an existing brass tube of $1.5 \mathrm{~m}$ long and approximately $0.45 \mathrm{~m}$ diameter (which stands for $2 r_{f}$ ), and fitted plates to close it at both ends. A thin central wire ran down inside the length of the tube. The closed tube and central wire acted as a short coaxial cable. At mid-length of the tube we cut a hole of about $82 \mathrm{~mm}$ diameter $\left(2 r_{0}\right)$ in the wall, where we mounted a sensor wire over the middle line. The transfer impedance between the tube and the sensor circuit was measured with a vector network analyzer over the frequency band of $100 \mathrm{kHz}$ up to $100 \mathrm{MHz}$. The S-parameters were converted into Z-parameters. For a sensor wire at the distance of $d=2 \mathrm{~mm}$ from the surface of the brass tube one has as mutual inductance between the tube inner circuit and the sensor wire: $M=\mu_{0}\left(r_{0}^{2}-d r_{0}\right) / 2 \pi r_{f}$. Between $1 \mathrm{MHz}$ and $10 \mathrm{MHz}$ the relation $\left|Z_{12}\right|=\omega M$ held to within 10 percent or better. This agreement is satisfactory because an increase of about $1 \mathrm{~cm}$ in distance between the central wire and the hole is well within the mechanical tolerance and suffices to explain the difference.

\subsection{New large scale tests}

May-June '09 tests are held at Airbus in Toulouse on an actual aircraft. When analyzed by the time of the conference, data from the sensors are presented.

\section{CONCLUSIONS}

Inductive sensors have earlier been developed for a freight railway test [6]. The EMC of the sensors has been optimized by the design. Generally, inductive sensors require integrators with good EMC properties and strong out-of-band rejection. Coaxial passive integrators have been developed for this purpose, followed by active integrators to redress the overall transfer.

Test in laboratory and on an aircraft [3] were successful. The coil sensors are of the good old and reliable type. The window sensor is new, although it bears resemblance to a slot antenna. Its main advantage is that no additional holes or feedthroughs in the fuselages are required for power and signal. As small scale model confirmed the analysis. The balanced shape of the figure ' 8 ' sensor enhances the sensitivity with respect to the intended field pattern. A more detailed analysis including the skin effect in the wall [2, Sect. G2] is still to be carried out.

In particular for the LF channel, solid state sensors have been investigated in parallel with the coil sensors. The solid state sensors also required the shielding to cope with the strokes. The details will be published elsewhere. As an alternative, the voltage drop over the fuselage can also be used for the quasi-continuous current. This solution has been developed indeed. The window sensor can be adapted to this purpose as well.

\section{Acknowledgments}

This work has been supported by the EU FP6 program, 'In-flight Lightning Damage Assessment System', project number 030806.

\section{References}

[1] EU FP6-030806

[2] H. Kaden, Wirbelströme und Schirmung in der Nachrichtentechnik, Berlin: Springer, 1959, 2nd ed.

[3] V. Stelmashuk, A. P. J. van Deursen, M. Webster, "Sensors for in-flight lightning detection on aircraft," in Proc. Int. Symposium on EMC, EMC Europe 2008, Hamburg, Germany, September 911, 2008, pp. 367-371.

[4] J.D. Jackson, Classical Electrodynamics, New York: Wiley, 1975, 2nd ed.

[5] on-line: www.feko.info

[6] A. P. J. van Deursen, H. W. M. Smulders, R. A. A. de Graaff, "Differentiating/integrating measurement setup applied to railway environment," IEEE Trans. on Instrum. and Meas., Vol. 55 1, Feb. 2006, pp. 316-326. 